\title{
LATE CRETACEOUS NAUTILID JUVENILES OF CYMATOCERAS REUSSI AND EUTREPHOCERAS AFF. SUBLAEVIGATUM - SCARCE FOSSILS UNDER RISK OF PYRITE DEGRADATION
}

\author{
JIŘÍ FRANK \\ JAN SKLENÁŘ \\ BORIS EKRT \\ National Museum, Department of Palaeontology, Václavské náměstí 68, 11574 Praha 1, the Czech Republic; e-mails: \\ jiri_frank@nm.cz; jan_sklenar@nm.cz; boris_ekrt@nm.cz
}

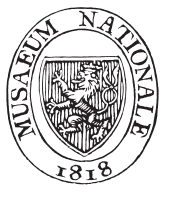

Frank, J., Sklenář, J. Ekrt, B. (2014): Late Cretaceous nautilid juveniles of Cymatoceras reussi and Eutrephoceras aff. sublaevigatum - scarce fossils under risk of pyrite degradation. - Acta Mus. Nat. Pragae, Ser. B, Hist. Nat., 70(3-4): 143-152, Praha. ISSN 1804-6479.

\begin{abstract}
The syntype collection of "Nautilus reussi" has been subject to a detailed revision resulting in confirmation of at least provisional validity of the species represented by a single juvenile specimen. This species, restricted now to the Late Coniacian, is inserted into the genus Cymatoceras Hyatt, 1884. The rest of the collection differs from the original description and is left separately as Eutrephoceras aff. sublaevigatum, being considered juveniles of the species. The lithology, geographic and stratigraphic position of the type locality of Cymatoceras reussi (FRITSCH IN FritSCH ET SCHLÖNBACH, 1872) as well as the other sites are discussed here. The valuable material is endangered due to pyrite degradation as relics of this unstable sulphide are still at present hidden in the secondary limonitic material. The degradation products cause volumetric expansion resulting in formation of crevices and loss of integrity. Some of them are corrosive and destroy labels and other attached documentation. Discussion of procedures which could be employed to prevent this valuable material from being lost are one of the objectives of the present study.
\end{abstract}

Bohemian Cretaceous Basin, nautilids, juvenile cephalopod shell, Late Turonian, Coniacian, limonitisation, pyrite degradation, collection care

Received May 28, 2014

Issued December, 2014

\section{Material}

The studied material represents 24 juvenile specimens from the collections of the National Museum. One specimen belongs to Cymatoceras reussi and 23 to Eutrephoceras aff. sublaevigatum. All specimens are listed in Tab. 1. and several are displayed in Pl. 1 and Pl. 2.

\section{Geology and Localities}

The type specimen of Cymatoceras reussi (FRITSCH IN FRITSCH ET SCHLÖNBACH, 1872) comes from quartzose, kaolin-rich sandstones outcropping on the southern hillside of Chlum elevation near Vinařice (Mladá Boleslav district; for locality settings see Text-Fig. 1). Frič (1897) indicated, that the specimen came from the "groben Sandstein" (i.e. coarse sandstone) which may indicate it originated from the thickest "mürber, grobekörniger" (i.e. brittle, coarse grained) sandstone layer (no. 6 in Frič's section). The sample rock supports this interpretation. Later correlation with the pelitic, distal, Coniacian sediments proved this unit to belong to distal parts of the siliciclastic bodies of the Březno Formation prograding from the nearshore areas of the presumed West Sudetic Island (see e.g. Čech et al. 1980, Uličný et al. 2009, Čech 2011). According to Klein and Soukup (1963) the sandstones with the rich fauna collected by Frič rank within the Xe $\beta$ lithounit (Soukup 1955). Recently, the stratigraphic position of the Vinařice outcrops have been reappraised by Svobodová et al. (in press). Their micropalaeontological analysis as well as revision of a texanitid ammonite from the Frič collection resulted in a well supported assessment of the Vinařice section as being Late Coniacian age.

Lenešice brickworks and the Březno localities are located in the vicinity of Louny, a town situated in NW Bohemia (Ohře region, the Czech Republic). All the studied specimens come from calcareous claystones containing rich pyritised (and subsequently limonitised) fauna. The layers have been called "gastropod beds" or "gastropod horizons" due to the multiple gastropods dominating their taphocenoses. Prevailing in the taphocenoses are cephalopods (baculitids, scaphitids), bivalves (oysters, small infaunal bivalves) sponges and ahermatypic corals. The first publication concerning the accumulations of pyritised fauna was presented by Reuss (1844) and concentrated on "Plännermergel" between Raná and Lenešice. The gastropod layers were described by Frič (1893) who produced extensive lists of abundant fossil taxa for the Březno and Lenešice brickworks outcrops and obtained a large amount of material for the National Museum ("Museum of the Kingdom of Bohemia") some of which he collected himself in addition to other collectors (Meyer, Feigel). Frič inserted both the horizons into his "Březno Beds" ("Priesener Schichten") 


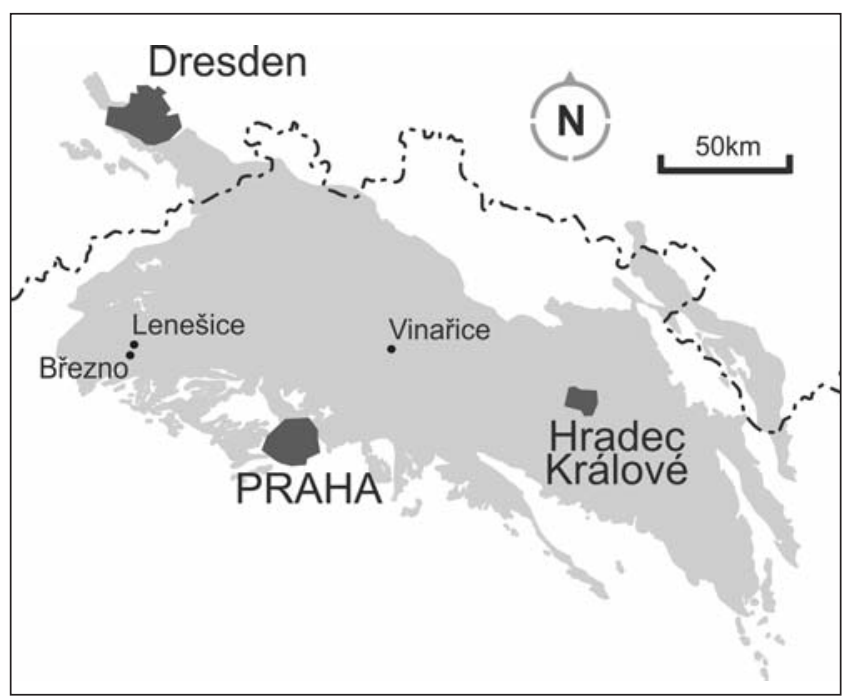

Text-fig. 1. Map of the Czech Republic with Bohemian Cretaceous Basin and localities from where the subscribed specimens originate highlighted.

and considered them as being synchronous. Since Frič's paper, more localities with claystones rich in pyritised taphocenoses have been detected in the Louny area - Lenešice "V Třesku", Lenešice "U Kláštera”, Velký Vrch near Vršovice (e.g. Macák 1967 ) and the slope south from Vojnice near Koštice (Váňa, 1999). Since that time, absolute stratigraphic position and relationships between these beds have been under discussion even though they were considered relatively diachronous (e.g. Č. Zahálka 1900, 1914, B. Zahálka 1938, Macák 1967, Krutský et al. 1975, Váně 1999). Macák (1967) stated that the "gastropod horizons" occur generally on three levels: the Lenešice brickworks layer is Late Turonian in age, Březno is the latest, formed in the Early Coniacean and the remainder are of Early Coniacean age, but before the gastropod layer in Březno.

The Lenešice brickworks locality used to represent one of the largest and best exposed outcrops in the Ohře region and also the most exploited locality for pyritised fauna in the Bohemian Cretaceous Basin. The geological situation in the Lenešice brickworks layer is complicated by multiple faults, dominating are ENE-WSW normal faults crossing the Raná and Chlum hills (Krutský et al. 1975, Váně 1999) and the gastropod layer slightly dips approximately westwards which led to confusion for B. Zahálka (1938), who distinguished two gastropod layers - lower and upper (see also Váně, 1999). The later Late Turonian age of the Lenešice gastropod horizon has been proven by Macáks' (1967) borehole which coincided with the phosphatic horizon marking the base of Teplice Formation 17.8 below the gastropod layer. Váně (1999) disputed Macák's conclusion assuming a much higher position above the base (about $30 \mathrm{~m}$ ). Prionocyclus germari (REUSS) reported by Krutský et al. (1975) from the gastropod layer of this locality confirms the later Late Turonian age. Finally, this gastropod layer was assigned to the Xc lithounit (sensu Soukup 1954; Macák 1967, Krutský et al. 1975, Váně 1999) and thus to the upper part of the Teplice Formation (sensu Čech et al. 1980).

Čech et al. (1980) designated the Březno outcrops as being the lithostratotype for the Březno Formation. Later Čech and Švábenická (1992) published a detailed description and palaeontological revision of the section. According to these authors the claystones outcropping in Březno are of early Middle Coniacian age. Fričs "gastropod bed" (lithounit Xc (Zahálka 1900)), which yielded limonitised nautiloids, falls into the uppermost part of the Cremnoceramus crassus (Petrascheck) occurrence interval and the FAD of Inoceramus kleini (Müller) was reported within the layer (Čech and Švábenická ibid.). Silty infill of some specimens (NM-O7140 - O7141) suggests they are more likely to have come from the basal part of the Brrezno outcrop falling into the so called Nucula Beds (sensu Čech and Švábenická (1992).

The juvenile specimen (NM-O7357) from Třebívlice Měrunice area near Lovosice comes from pyrope-bearing gravels. This sediment is of Cenozoic (Pleistocene) origin and represents colluvial/fluvial accumulations of pyrope, siliciclastics and redeposited limonitised fauna released from Late Cretaceous sediments in the close vicinity (e.g. Sýkora 1952).

Tab. 1 - list of studied specimens, for locality settings see Text-Fig. 1.

\begin{tabular}{|c|c|c|c|}
\hline Coll. num. & Name & Locality & Stratigraphy \\
\hline NM-O3166 & Cymatoceras reussi & Vinařice (Dobrovice) & Late Coniacian \\
\hline NM-O7137 & Eutrephoceras aff. sublaevigatum & Březno (Louny) & Middle Coniacian \\
\hline NM-O7140 & Eutrephoceras aff. sublaevigatum & Březno (Louny) & Middle Coniacian \\
\hline NM-O7141 & Eutrephoceras aff. sublaevigatum & Březno (Louny) & Middle Coniacian \\
\hline NM-O7139 & Eutrephoceras aff. sublaevigatum & Březno (Louny) & Middle Coniacian \\
\hline NM-O7357 & Eutrephoceras aff. sublaevigatum & Třebívlice - Měrunice & redeposited \\
\hline PM2-6/2006 & Eutrephoceras aff. sublaevigatum & Lenešice (Louny) & Late Turonian? \\
\hline NM-O7142 & Eutrephoceras aff. sublaevigatum & Lenešice - brickyard & Late Turonian \\
\hline NM-O7143 & Eutrephoceras aff. sublaevigatum & Lenešice - brickyard & Late Turonian \\
\hline NM-O7144 & Eutrephoceras aff. sublaevigatum & Lenešice - brickyard & Late Turonian \\
\hline NM-O7145 & Eutrephoceras aff. sublaevigatum & Lenešice - brickyard & Late Turonian \\
\hline NM-O3167 & Eutrephoceras aff. sublaevigatum & Lenešice & Late Turonian? \\
\hline NM-O6838 & Eutrephoceras aff. sublaevigatum & Březno (Louny) & Middle Coniacian \\
\hline NM-O6839 & Eutrephoceras aff. sublaevigatum & Březno (Louny) & Middle Coniacian \\
\hline NM-O6844 & Eutrephoceras aff. sublaevigatum & Březno (Louny) & Middle Coniacian \\
\hline NM-O7134 & Eutrephoceras aff. sublaevigatum & Březno (Louny) & Middle Coniacian \\
\hline NM-O7135 & Eutrephoceras aff. sublaevigatum & Lenešice & Late Turonian? \\
\hline NM-O7138 & Eutrephoceras aff. sublaevigatum & Březno (Louny) & Middle Coniacian \\
\hline
\end{tabular}




\section{Systematic Palaeontology}

\section{Cymatoceras reussi \\ (Fritsch IN Fritsch et SChlönbaCh, 1872)}

$$
\text { Pl. 1, fig. } 1
$$

non 1845 Nautilus inaequalis SOWERBY; Reuss, p. 21, pl. 7, fig. 12.

p. 1872 Nautilus reussi Fr. IN FritsCh et SChLÖNBACH, p. 25 , pl. 12, figs. 4.a,b.

$1897 \quad$ Nautilus reussi Fr.; Frič, p. 36.

1898 Nautilus reussi FR.; Frič, p. 35.

p. 1934 Nautilus reussi Frič; Andert, p. 392.

p. 1956 Nautilus reussi Fritsch ET SCHLÖNBACH; Kummel, p. 344.

Lectotype: NM-O3166. The specimen is in the collections of the National Museum in Prague. This specimen is the only one preserved and figured specimen of $C$. reussi which according to the emended diagnoses can be determined as the lectotype. The rest of the syntype collections after this revision belong to Eutrephoceras aff. sublaevigatus.

Typ e loc al ity: Vinarice near Dobrovice.

Ty pe h o r i z o n: Upper Coniacian, Březno Formation, Frič's layer No.6 (?).

Emended diag n o si s. Nautiliconic, involute shell, slightly compressed whorl in cross section, broadly rounded ventral side, numerous phragmocone chambers, sinuous suture line with umbilical saddle, prominent lobe on the inner lateral side, saddle on the lateral side, lobe on the outer lateral side and saddle on the ventral side. Siphuncle barely noticeable in central/ventro-central position. Reticular sculpture on the surface of early juvenile shell (This diagnoses is based on the single juvenile specimen NM-O3166).

Discussion. A. Frič described (in Fritsch and Schlönbach, 1872) several specimens from Chlomek, Březno and Lenešice locality and identified them as a new species "Nautilus reussi". Nevertheless the group of specimens described by Frič contains two different species. One of the specimens, NM-O3166 (Pl. 1, fig.1), can be correctly considered as a new species, Cymatoceras reussi, due to its specific suture line and numerous phragmocone chambers. As Frič mentioned himself, this specimen is unique in its morphology among the Bohemian Cretaceous Basin cephalopod fauna and it was for this reason that he described it as a new species. The specimen represents initial juvenile whorls of a larger specimen as indicated by the umbilical columns. The reticular pattern on the surface represents the typical surface morphology of nautilid juveniles in the pre-hatching state (e.g. Chirat 2001; Arnold et al. 2009). The other specimens from the group are described in this study as Eutrephoceras aff. sublaevigatum.

Frič considered C. reussi as a potential juvenile specimen of Cymatoceras deslonghampsianum (D'ORBIGNY, 1840) from the Cenomanian. This species has numerous chambers and a similar sinuous suture line but less prominent ventral saddle. Specific for $C$. deslonghampsianum are the prominent radial ribs with fine cross lines emerging during ontogeny after hatching which Frič also considered in his comparison. In the pre-hatching state there are the same reticular patterns as in all other post Triassic nautilids. Another specific feature is the prominent sharp edge on the umbilical inner lateral side. This feature cannot be confirmed on the C. reussi juvenile specimen due to its state of preservation. The siphuncle position in C. deslongchampsianum is centrodorsal, but on $C$. reussi it seems to be central or slightly ventro-central.

Other Cenomanian species resembling C. reussi in its multiple chambered phragmocone and suture line are Cymatoceras subradiatus (D'ORBIGNY, 1850) and Cymatoceras cenomanense (SCHLÜTER, 1876) (actually a synonym of the former, Frank et al. in prep). These species have a similar suture line with shallow ventral saddle, but the position of the siphuncle is central - dorso-central.

C. reussi may also be considered a juvenile specimen of Cymatoceras patens (KNER, 1848) reported from the Maastrichtian due to its similar suture line with shallow ventral lobe and similar siphuncle position which is slightly above the centre in early ontogeny and centro-ventral in late ontogeny. This species features specific ribbing consisting of flattened lamellae with sharp edges in later ontogenic stages and a compressed shell with trapezoidal whorl cross section. Unfortunately, there are no preserved early juvenile specimens of $C$. patens to compare with C. reussi. However, the occurrences of the species are considerably distant in their stratigraphical position.

Until later ontogenetic stages, essential for comparison with other Late Cretaceous nautilids, are found, C. reussi should be kept as a valid taxon.

O c c u r r e n c e: Vinarice, Lower Coniacian, the Czech Republic.

\section{Eutrephoceras aff. sublaevigatum (D'ORBIGNY, 1850)}

$$
\text { Pl. 1, fig. 2; Pl. 2, figs 1-8 }
$$

$1840 \quad$ Nautilus laevigatus D’ORBIGNY, 1, s. 84, tab. 17. non 1845 Nautilus inaequalis SOWERBY; Reuss, p. 21, pl. 7 , fig. 12.

$1850 \quad$ Nautilus sublaevigatus D’ORB.; d'Orbigny p. 189.

1872 Nautilus reussi Fr. IN FritsCh ET SCHLÖNBACH, p. 25 , pl. 12, fig. 5a-c.

1893 Nautilus reussi Fr.; Frič, p. 73, fig. 47.

$1895 \quad$ Nautilus reussi Fr.; Frič, p. 71, fig. 47.

$1934 \quad$ Nautilus reussi Frič; Andert, p. 392.

1956 Nautilus reussi FrITSCH ET SCHLÖNBACH; Kummel, p. 344.

2007a Eutrephoceras sp.; Frank, p. 112.

2007b Eutrephoceras sp.; Frank, p. 35.

De s c ription. Specimens have nautiliconic, involute ovoidal shell with depressed broadly rounded whorl cross section on ventral and lateral sides. The suture line is very simple with a relatively shallow lateral lobe and shallow/ almost straight ventral lobe. The umbilicus is broad, not completely filled with shell material, which could result from the method of preservation. The siphuncle is in a central 
position. Where the shell is partly preserved early juvenile reticular patterns (Pl. 2, figs. 2b, 4a, 5b-c,) or prominent growth lines (Pl. 2, fig. 8c) are noticeable.

D i s c u s s i o n. Other determined specimens of Frič's "Nautilus Reussi" are most probably juveniles of Eutrephoceras sublaevigatum (D'ORBIGNY, 1840). Those specimens are similar in simple suture line, shape of the shell, whorl cross section as well as siphuncle position. There are no specimens of later ontogenetic stages or complete juvenile specimens with preserved living chamber and thus features firmly indicating ranking within E. sublaevigatum are absent. Therefore these specimens are left here in open nomenclature as Eutrephoceras aff. sublaevigatum.

Frič (in Fritsch and Schlönbach, 1872) synonymized $E$. aff. sublaevigatum juvenile specimens with Nautilus inaequalis (SOWERBY, 1812) which was described in detail by Reuss in 1845 , but according to the description and figures, the latter species differs from $E$. aff. sublaevigatum in its almost flattened ventral side and centro-dorsal position of the siphuncle.

Prominent growth lines on the juveniles are very similar to Eutrephoceras expansum (SOWERBY, 1824) from the Cenomanian, but this species differs by its sinuous suture line with prominent lateral lobe.

There are fragments of shell preserved on the right lateral side of specimen NM-O7134 (Pl. 2, fig. 1b). This specimen was figured by Frič $(1893,1895)$ with a reconstructed living chamber. The shell is affected by diagenesis but still includes a considerable percentage of aragonite constituting the original shell. When examined by means of SEM, typical nacreous ultrastructure, consisting of flat hexagonal crystals arranged in columns, is still distinguishable (Pl. 3, fig. 2). This ultrastructure is comparable with the fabric of the nacreous layer of a modern nautiloid shell (Pl. 3, fig. 1).

O c c u r r e n c e: Czech Republic, Bohemian Cretaceous Basin - Březno (Louny district, Lower Coniacian), Lenešice (Louny district, Late Turonian), Třebívlice-Měrunice area (Lovosice district, redeposited in Pleistocene sediment).

\section{Pyritization and pyrite degradation}

All the three-dimensionally preserved fossils of nautiloid shells from the Late Turonian - Early Coniacean marlstones of Lenešice and Březno localities as well as the redeposited specimen from the Třebívlice-Měrunice area contain considerable amounts of ferrous compound. This consists of Fe oxides/hydroxides (limonite) and Fe disulphide (pyrite), in variable proportions. The synsedimentary or early diagenetic precipitation of ferrum sulphides in aerobic to dysaerobic conditions is generally associated with microenvironments enriched with $\mathrm{H}_{2} \mathrm{~S}$ (see e.g. Brett and Baird 1986). Such conditions occur in shells as well as some ichnofossils due to the decay of organic matter. Disulphide formation usually passed from a monosulphide precursor (mackinawite, greigite), precipitated in these anoxic conditions, to a more stable disulphide (i.e. pyrite; Wilkin and Barnes 1997)

The rapid nucleation of the original pyrite in shells buried in Lenešice, Vršovice and Březno marls is well supported by the inverse ratio of the compaction rate to ferrum content in the inner moulds. Precipitation or crystallisation of the sulphide was usually associated with the shell surface and in many cases sulphide locally penetrated its wall even though relatively weakly. This may be observed in SEM photographs (P1. 3, fig. 2) showing intensive dissolution of the primarily aragonite crystal, being substituted with ferrous compound (originally $\mathrm{FeS}_{2}$ ). Formation of massive anhedral pyrite resulting in perfect inner casts shows clear preference for initial portions of the internal shell: juvenile chambers of nautiloids. This phenomenon, also observed in ammonites and aboral coils of gastropods typical for the Lenešice taphocenosis, can be interpreted as being the result of high content of trapped decay products, dimensions of the low-permeable trap themselves. The initial absence of sedimentary infill might also play a role in the process.

Later the primary rock was exposed to leakage of oxygenated fresh water as it became closer to the surface due to postmesozoic exhumation. The shift in redox conditions resulted in oxidation of sulphidic steinkerns enclosed in clayey material. The product of this process is a mixture of ferrum oxides and hydroxides (limonite) coating the surface of the natural moulds, forming powdery enclaves or even almost totally substituting the primary sulphidic mass. In general, there are, however, always some relicts of original disulphide present in the central portions of those specimens which had been completely sulphidised.

The remains of disulphide (pyrite) as well as degradation products represent a source of serious hazard in collection care. This compound is very unstable, the disulphide is easily oxidised which leads to chain processes of degradation. The resulting products of $\mathrm{Fe}$ sulphates produce a series of multihydrates (1-7). The gradual hydration is accompanied by considerable expansion and this results in cracking up of fossils (Blount 1993). The processes are accelerated by various hygroscopic products ( $\mathrm{Fe}$ and $\mathrm{Al}$ sulphates and sulphuric acid) enriching the system with water solvent. Fossil disintegration is also influenced by clay mineral components which swell when saturated by water and also provide a reservoir for product accumulation.

All the volume changes cause destruction of fossils, but also affect the general shape. As the pyrite in the "Lenešice" fossils occurs mostly on shale interfaces, the expansion on cephalopod septa influence general interseptal rate and can result in a shift in shell (inner mould) dimensional proportions.

\section{Recommended treatment}

With respect to particular material with possible but not necessarily obvious active decay, it is recommended to exclude hazardous factors. Optimal treatment is to enclose specimens in a case nonpermeable to oxygen and moisture. The dry and oxygen-free internal conditions must be adjusted by oxygen and moisture scavengers (see Day, 2005).

Fragile and complicated specimens should be impregnated by consolidants (e.g. Paraloid B72) and eventually stuck together. Prior to this, hygroscopic products should be removed by mechanical and chemical methods or passivated. Before radical treatment, the volume of products 
must be considered: morphological information or specimen coherence, can be comprised of decay products only!

Chemical passivation by ammonia gas (Waller 1987) is somewhat unsuitable for this material because of the insufficient depth penetration (Howie 1979; fide Newman 1998) due to low permeability caused by very low primary porosity or ferrous cement secondarily filling the pores. For this material, more efficient may be passivation by ethanolamin thioglycolate (for more details see Cornish and Doyle 1984). This method however is very time consuming and large amounts of the solution have to be utilised. Cleaning using the Cornish-Doyle method is in this case an endless process. The method suggested here is to decrease the hygroscopic content before sealing the specimens in microenvironment rather than to clean the specimens thoroughly.

If just a thin limonite layer occurs on the fossil surface and it is necessary to clean it, the Waller method can be used (Waller 1980; King 1983)

\section{Conclusions}

The collection itself serves as a good example of taxonomical difficulties arising from the record formed in taphonomic conditions which allow just juveniles or rather only initial stages of further developed shells to persist. In such a situation, the relationship to other known species tends to be rather ambiguous. The revision of Frič's syntype collection of "Nautilus Reussi" results in confirmation of the validity of the reussi species, which is here inserted into the Cymatoceras genus. The rest of the syntype collection is determined as Eutrephoceras aff. sublaevigatum. The Frič collection of nautiloid juveniles and initial shell samples is very valuable from both the historical and taphonomic viewpoints. Therefore possibilities for preservation of this material endangered by pyrite degradation are discussed. Despite the fact that Cymatoceras reussi is based on a single juvenile specimen, it is accepted here as valid, because of the noticeable features distinguishing it from other Late Cretaceous dated nautilid juveniles. There are potential candidates in the Cenomanian or Maastrichtian which this juvenile may be associated with, but the relationship cannot be confirmed without more material, especially specimens of later ontogenetic stages. Until then $C$. reussi must be considered a valid species. The other specimens from the syntype collection show high affinity to Eutrephoceras sublaevigatum, but due to the absence of specimens with preserved features of later ontogenetic stages from the same horizon, these specimens are left in open nomenclature as Eutrephoceras aff. sublaevigatum. The valuable Frič syntype collection is endangered by processes related to degradation of incorporated pyrite relics. Therefore, considerable attention is given here to applicable treatment methods. As far as possible, the degradation products should be removed using available methods (in particular the Cornish-Doyle method) and specimens enclosed in oxygen and moisture free microenvironments. The taphonomy of the fossil fauna from the Lenešice locality is subject to further study with respect to specific conditions of preservation which are among the issues closely related to care of the collection.

\section{Acknowledgements}

We would like to express our thanks to Lenka Váchová, who took the photos of the specimens, and to both the reviewers Vojtěch Turek and Martin Košták for their beneficial comments. The research was supported by project NAKI DF12P01OVV031 "Preventive and remedial conservation methodology for the collection specimens falling within palaeontology and mineralogy endangered by sulphide degradation products".

\section{References}

Andert, H. (1934): Die Kreideablagerungen zwischen Elbe und Jeschken. III. Die Fauna der obersten Kreide in Sachsen, Böhmen und Schlesien. - Abhandlungen der Preußischen Geologischen Landesanstalt, Neue Folge 159: 1-477.

Arnold, J. M., N. H. Landman, Mutvei. H. (1987): Development of the embryonic shell of Nautilus. - In: W. B. Saunders and N. H. Landman (eds), Nautilus. Plenum Press, New York, pp. 373-400.

Blount, A. M. (1993): Nature of the alterations which form on pyrite and marcasite during collection storage. Collection Forum 9(1): 1-16.

Brett, C. E., Baird, G. C. (1986): Comparative taphonomy: a key to paleoenvironmental interpretation based on fossil preservation. Palaios 1(3): 207-227. http://dx.doi.org/10.2307/3514686

Chirat, R. (2001): Anomalies of embryonic shell growth in post-Triassic Nautilida. - Paleobiology 27(3): 485-499.

Cornish, L. Doyle, A. M. (1983): Ethanolamine Thioglycollate as a chemical agent for the neutralization and removal of oxidised pyrite. - The Geological Curator, 3(8): 512-513.

Čech, S., Klein, V., Kř́žž, J., Valečka, J. (1980): Revision of the Upper Cretaceous stratigraphy of the Bohemian Cretaceous Basin. - Věstník ústředního ústavu geologického, 55: 227-296.

Čech, S., Švábenická, L. (1992): Macrofossils and nannofossils of the type locality of the Březno Formation (Turonian-Coniacian, Bohemia). - Věstník českého geologického ústavu, 67(5): 311-326.

Čech, S. (2011): Palaeogeography and stratigraphy of the Bohemian Cretaceous Basin (Czech Republic) - an overview. - Geologické výzkumy na Moravě a ve Slezsku 18(1): 18-21.

Day, J. (2005): Practical application of the Revolutionary Preservation (RP) System $^{\circledR}$ for marcasite. - ICOM Committee for Conservation 1, pp. 435-442.

Frank, J. (2007a): Upper Cretaceous nautiloids of epicontinental seas in Central Europe - Bohemian Cretaceous Basin. - Seventh International Symposium Cephalopods - Present and Past, Sapporo (Japan), Abstracts, pp. 112-113.

Frank, J. (2007b): Nautiloidea české křídové pánve. - 8 . paleontologická konferencia, zborník abstraktov. Štátny geologický ústav Dionýza Štúra, Bratislava, pp. 35-36.

Frič, A. (1893): Studien im Gebiete der Böhmischen Kreideformation; V. Priesener Schichten. - Archiv 
Naturwissenschaften Landesdurchforschung Böhmen 9(1): 1-130.

Frič, A. (1895): Studie v oboru křídového útvaru v Čechách; Paleontologické prozkoumání jednotlivých vrstev; V. Březenské vrstvy. - Archiv pro prŕírodovědecké prozkoumání Čech, 9(1): 1-130.

Frič, A. (1897): Studien im Gebiete der Böhmischen Kreideformation; Paläontologische Untersuchungen der einzelnen Schichten. VI. Die Chlomecker Schichten. Archiv der naturwissenschaftlich Landesdurchforschung von Böhmen 10(4): 1-84.

Frič, A. (1898): Studie v oboru křídového útvaru v Čechách; Paleontologický výzkum jednotlivých vrstev; VI. Chlomecké vrstvy. - Archiv pro prrírodovědecké prozkoumání Čech, 10(4): 1-81.

Fritsch, A., Schlönbach, U. (1872): Cephalopoden der böhmischen Kreideformation. - Published by the authors, Prag. 52 pp.

Howie, F.M.P. (1979): Museum climatology and the conservation of palaeontological material. - In: Bassett, M. G. (ed.), Curation of palaeontological collections, Special Papers in Palaeontology, 22: 103-125.

King, R.J. (1983): The care of minerals, section 2: The development of minerals. - Journal of the Rusell Society 1(2): 54-77.

Klein, V., Soukup, J. (1963): Křída. Vysvětlivky k přehledné geologické mapě ČSSR 1:200000, M-33-XV, Praha. Ústřední ústav geologický, Praha, 220 pp.

Kner, R. (1848): Versteinerungen des Kreidemergels von Lemberg und seiner Umgebung. - Naturwissenschaftliche Abhandlungen Haidinger, 3, Abt. 2: 1-42.

Krutský, N., Váně, M., Holá, A., Hercogová, J. (1975): Turon a coniak v dolním Poohří. - Sborník geologických věd, 27: 99-142.

Kummel, B. (1956): Post-Triassic Nautiloid genera. Bulletin of the Museum of Comparative Zoology at Harvard College in Cambridge, 114: 319-494.

Macák, F. (1967): Stratigrafická pozice tzv. gastropodových horizontů $\mathrm{v}$ zípadním Poohří. - Věstník Ústředního ústavu geologického, 42: 213-215.

Newman, A. (1998): Pyrite oxidation and museum collections: A review of theory and conservation treatments. - The Geological Curator 6 (10): 363-371.

Orbigny, A. d' (1840-1842): Paléontologie Française. Terrain Crétacé I, Céphalopodes. - Masson, Paris, 662 pp.

Orbigny, A. d' (1850): Podromme de paléntologie stratigraphique universelle des animaux mollusques et rayonnés. - Masson, Paris, 394 pp.

Reuss, A. E. (1844): Geognostische Skizzen aus Böhmen. Zweiter Band. - Die Kreidegebilde des westlichen Böhmens, Prag, 304 pp.

Reuss, A.E. (1845): Die Versteinerungen der Böhmischen Kreideformation. Erste Abtheilung. - E. Schweizerbart'sche Verlagsbuchhandlung, Stuttgart, $58 \mathrm{pp}$.

Schlüter, C. (1876): Cephalopoden der Oberen Deutschen Kreide. 2. Abtheilung. - Palaeontographica, 24: 123-255.

Soukup, J. (1955): Úprava stratigrafického členění a otázka hranice mezi turonem a senonem v české křídě. - Sborník Ústředního ústavu geologického 21(2): 1-41. [with Russian and German resume]
Sowerby, J. (1812): The Mineral Conchology of Great Britain; or coloured figures and descriptions of those remains of testaceous animals which have been preserved at various times and depths in the earth. I. London, vii + 234 pp.

http://dx.doi.org/10.5962/bhl.title.14408

Svobodová, A., Košt’ák, M., Čech, S., Švábenická, L. (2014): New biostratigraphic evidence (texanitid ammonites, inoceramids and calcareous nannofossils) for the Upper and the uppermost Coniacian in the Bohemian Cretaceous Basin. - Zeitschrift der Deutschen Gesellschaft für Geowissenschaften (in press) http://dx.doi.org/10.1127/zdgg/2014/0023

Sýkora, L. (1952): Ložiska pyropů v Českém středohoří. Geotechnika 14: 1-24. [with Russian and French resume]

Uličný, D., Laurin, J., Čech, S. (2009): Controls on clastic sequence geometries in a shallow-marine, transtensional basin: the Bohemian Cretaceous Basin, Czech Republic. - Sedimentology 56(4): 1077-1114. http://dx.doi.org/10.1111/j.1365-3091.2008.01021.x

Váně, M. (1999): Geologie Lounska pro třetí tisíciletí. Chomutov, $471 \mathrm{pp}$.

Waller, R. (1980): A rust removal method for mineral specimens. - Mineralogical Record, 11: 109-110.

Waller, R. (1987): An experimental ammonia gas treatment method for oxidised pyritic mineralspecimens. - Triennial Report, ICOM Committee for Conservation, pp. 623-630.

Wilkin, R. T., Barnes, H. L. (1997): Formation processes of framboidal pyrite. - Geochimica et Cosmochimica Acta, 61(2): 323-339. http://dx.doi.org/10.1016/S0016-7037(96)00320-1

Zahálka, B. (1938): Geologická mapa kraje mezi Lenešicemi, Břvany a Hrádkem a nové názory na stratigrafii křídy poohárecké. - Spisy vydávané Př́rodovědeckou fakultou Masarykovy university 264, 71 pp.

Zahálka, Č. (1900): Pásmo IX (Březeňské) křídového útvaru v Poohří. - Věstník Královské České Společnosti Nauk, třída mathematicko-př́rodovědecká, 1899: 1-103. 


\section{Explanations of the plates}

\section{PLATE 1}

Cymatoceras reussi (FRITSCH IN FRITSCH ET SCHLÖNBACH, 1872), lectotype NM-O3166 figured in Fritsch and Schlönbach (1872) on plate 12. figure $4 a, b$

Scale bar of all figures $5 \mathrm{~mm}$.

1a. left lateral side, arrow is pointing to the reticular patterns on the surface;

1b. right lateral side

1c. dorsal side with visible suture lines

1d. ventral side, the arrow is showing potential position of siphuncle (cannot be confirmed because of the preservation);

1e. dorsal front side, the arrow is pointing to the suture lines with remarkable lobe on the ventral side;

1f. anterior side, the arrow is pointing to the suture lines, also visible are the reticular patterns on the left side of the specimen image with a noticeable umbilical column;

$1 \mathrm{~g}$. posterior side; the arrow is pointing to the umbilical column;

1h. dorsal side of the specimen in the sediment as it is displayed on the figure in Fritsch and Schlönbach (1872);

1i. right lateral side of the specimen in sediment as it is figured in Fritsch and Schlönbach (1872) but in reverse.

Eutrephoceras aff. sublaevigatum (D'ORBIGNY)

2a. Specimen NM-O3167 figured in Fritsch and Schlönbach (1872) on plate 12 . figure $5 a-b$ :

2b. Dorsal view of the specimen which is partly distorted due to the poor preservation caused by degradation of pyrite.

\section{PLATE 2}

\section{Eutrephoceras aff. sublaevigatum (D'ORBIGNY)}

Scale bar of all figures $5 \mathrm{~mm}$.

Specimen NM-O7134 figured by Frič (1893, 1895, fig. 47)

1a. left lateral side;

1b. right lateral side, the arrow is pointing to the relict of the shell from where the sample was taken to observe shell structure displayed in Pl. 3;

1c. ventral side;

1d. dorsal side.

Specimen PM2-5/2006 showing the average phase of pyrite degradation

2a. ventral side with pyrite degradation inside the phragmocone chambers, the arrow is pointing to the central position of the siphuncle;

$2 \mathrm{~b}$. dorsal side, the arrow is pointing to the remarkable reticular patterns

Specimen NM-O7135

3a. left lateral view;

3b. ventral view, the arrow indicates the central position of the siphuncle;

3c. posterior side, the arrow is pointing to the chamber destroyed by pyrite degradation;

3 d. dorsal side.
Specimen NM-O7145

4a. right lateral side, the arrow is pointing to the remarkable reticular patterns;

4b. dorsal side, the arrow is pointing to the reticular patterns.

Specimen NM-O6839, larger specimen with preserved relics of the shell and fine reticular pattern on the surface

5a. left lateral view;

5b. right lateral view, the arrow is pointing to the limonitised part of the shell with fine reticular pattern;

5c. dorsal side, the arrow is pointing to the limonitised part of the shell with fine reticular pattern;

$5 \mathrm{~d}$. ventral side.

Specimen NM-O7142 noticeably affected by pyrite degradation

6 a. right lateral view;

6b. left lateral view;

$6 c$. dorsal view.

Specimen NM-O7144 noticeably affected by pyrite degradation

7a. right lateral view;

7b. dorsal view;

7c. posterior view.

Specimen NM-O7138

8a. right lateral view;

8 b. left lateral view;

$8 \mathrm{c}$. dorsal view, the arrow points to the reticular patterns on the shell relic.

\section{PLATE 3}

Shell microstructure of nacre layer in Nautilus pompilius (LINNÉ)

1. Detail of nacre layer with aragonite crystals with fine darker layers of conchioline, the hexagonal aragonite crystals are in the fig orientated vertically and in lateral view produce column-like structure on low magnification.

\section{Eutrephoceras aff. sublaevigatum (D'ORBIGNY)}

Specimen PM2-6/2006

$2 \mathrm{a}$. the fragment of nacre layer from the inner side shows a structure similar to the lamellar structure of recent nautilus under higher magnification;

$2 b$. the edge of the nacre layer on the inner side, detail of the image 2a;

2c. closer detail of the edge from the previous image with noticeable lamellar structure on one distorted column and detail of the hexagonal aragonite crystal in the middle;

$2 \mathrm{~d}$. detail of the surface of the nacre layer with distorted columns with lamellar structure;

2e. detail of the eroded surface of the inner side of the nacre layer. 
PLATE 1

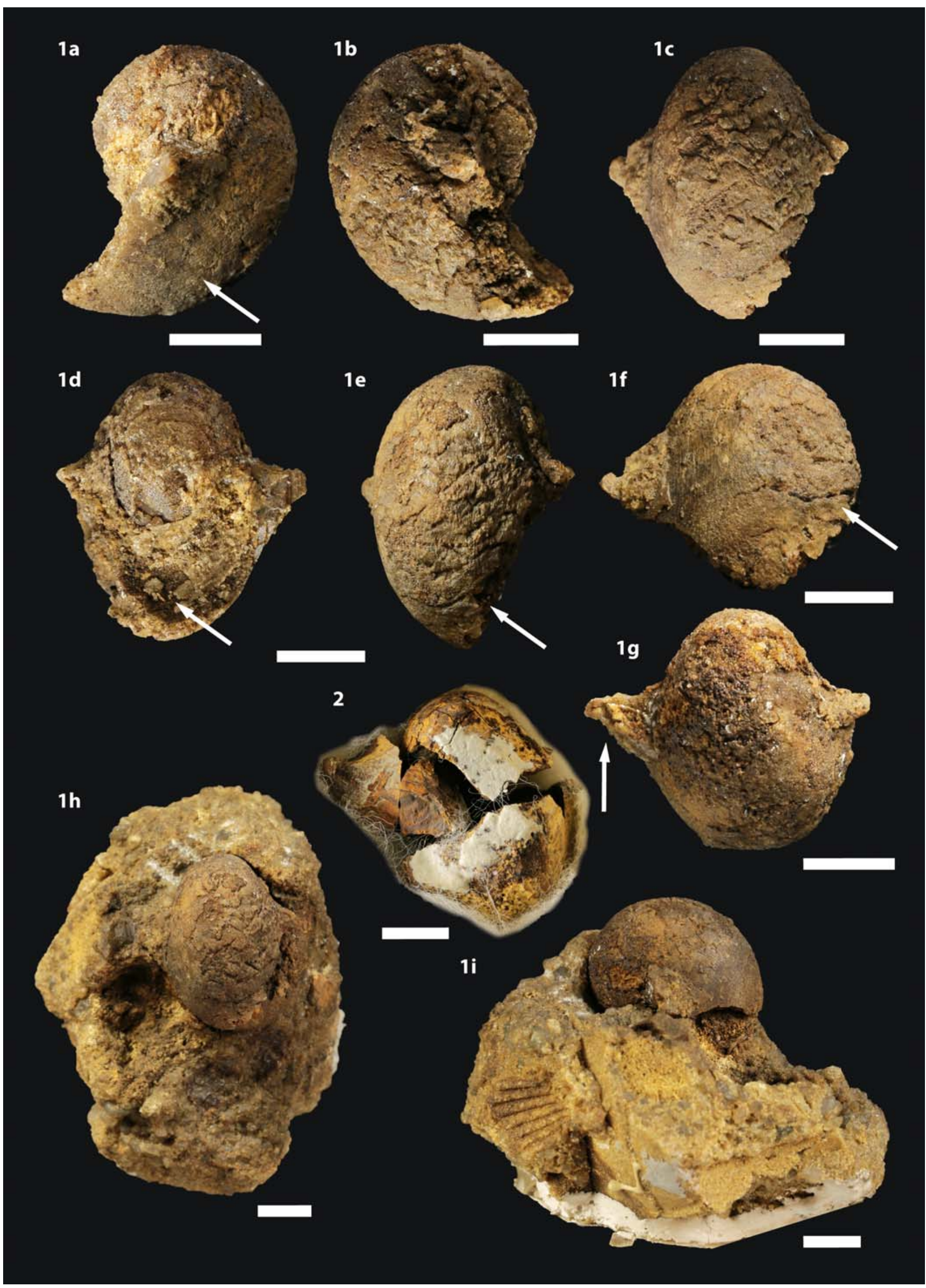


PLATE 2

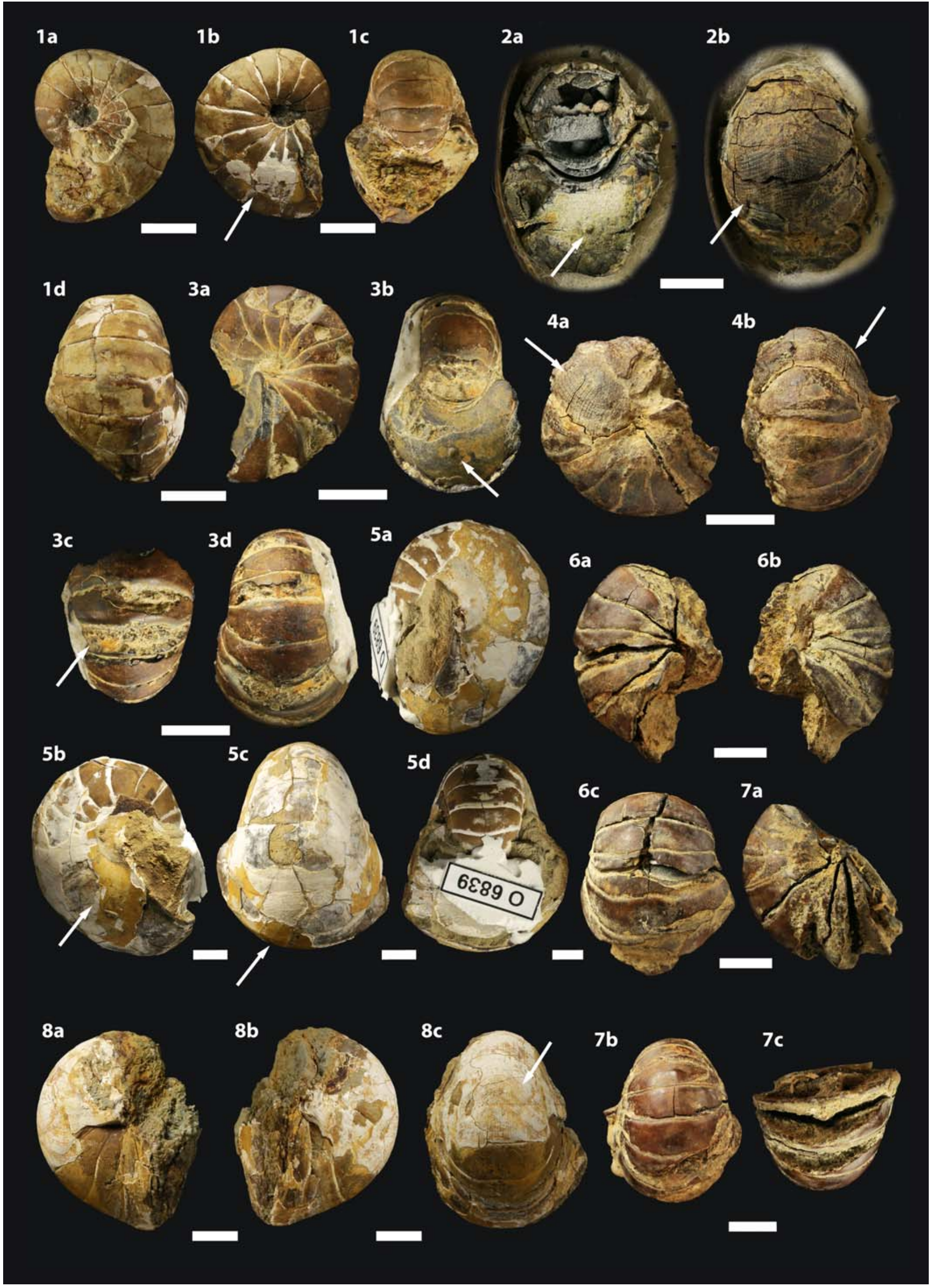




\section{PLATE 3}
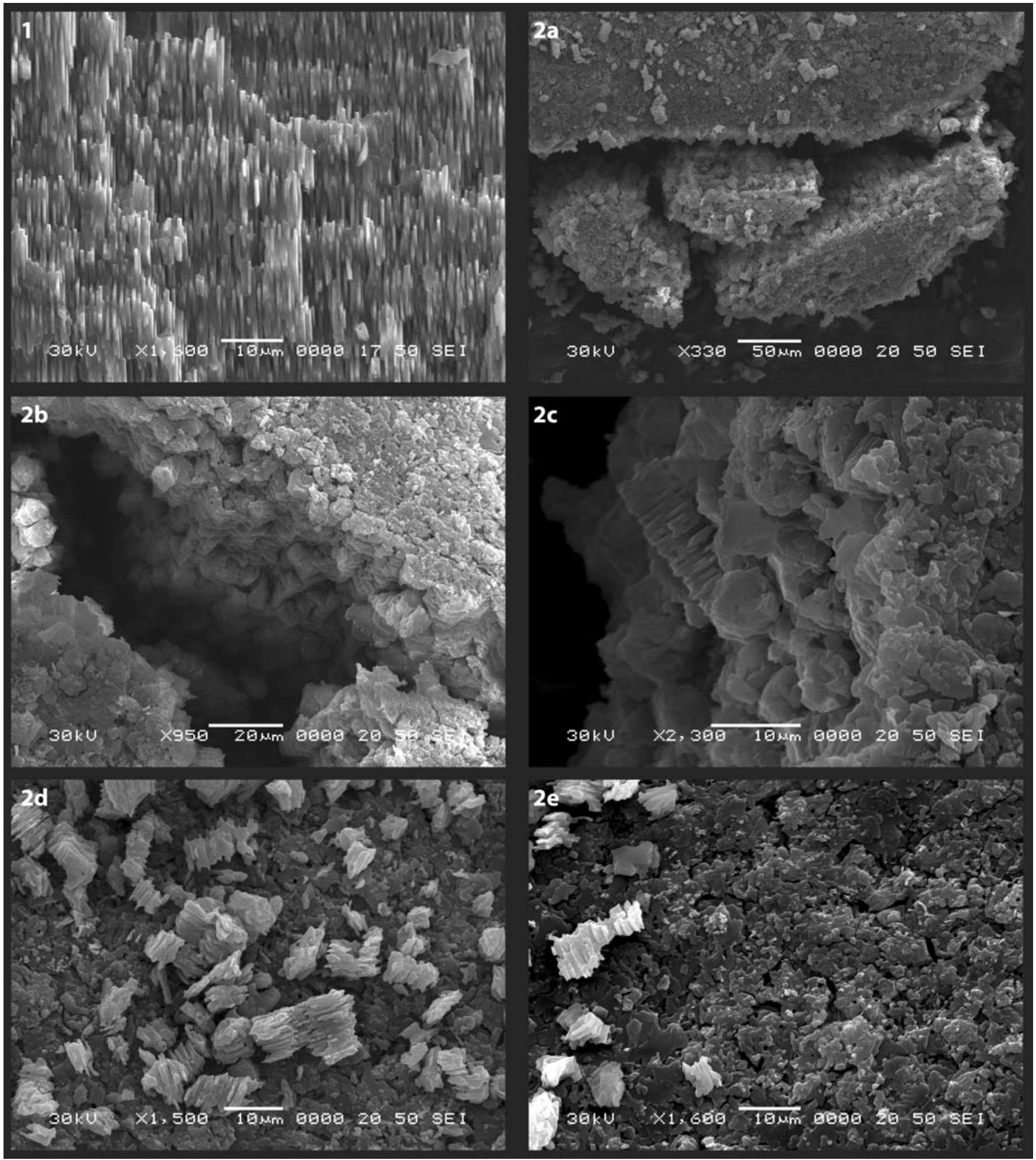